\title{
Non-Performing Assets (NPAs) of Urban Co-operative Banks (UCBs) in Coimbatore District of Tamil Nadu: An Empirical Study
}

\author{
P. Selvaraju \\ Assistant Professor and Head, Department of Co-operative Management, \\ Rajiv Gandhi Arts and Science College, Thavalakuppam, Puducherry-605 007, India \\ E-Mail: mpselvaraju@gmail.com
}

\begin{abstract}
Co-operation is a special method of doing work jointly and suits the poor more than the rich. The rich, however, are not precluded from coming with its fold. All those who want to co-operate must, as a condition precedent, have a common need and to fulfill it, should agree to work selflessly. The origin of Indian Co-operative Credit Movement can be traced as far back as to $\mathbf{1 8 4 4}$ as per the Report of Woodhead Famine Commission of Bengal Province. The said commission recommended that credit should be given at low rate of interest to the needy people. The Maclagan Committee's recommendations (1914) have much to contribute in evolving the urban cooperative credit movement and such banks have started developing in all the states of the nation. Banking is a service industry. The main objective of the banking is to provide the financial support to its customers / members in cooperatives. The Urban Co-operative Banks (UCBs) occupy a significant place in the urban credit movement. The urban cooperative credit movement started in India with the chief object of catering to the banking and credit requirements of the urban middle class. The expanding NPAs in banking Industry are a major concern for banking industry. NPAs affect the performance of banks and growth in NPA which bring down the entire profitability of the sector. In backlash of this situation, the core objectives of this empirical study to bring the real status and conditions of Non-Preforming Assets in Urban Co-operative Banks in Coimbatore District of Tamil Nadu. Further, the study can explore the factual outlook and effects of the same on different heads such as assets classifications (Standard asset, sub-standard, Doubtful Assets 1(D1),D2 and D3 Assets, Loss Assets, Sector-wise analysis, Gross and Net NPAs etc., all about, the findings of this empirical study can give a better understanding about the sector to the people who are associated with academic, research scholars, banking professionals, policy makers and consultant are in particular and allied groups are in general.

Keywords: Co-operative Bank, Non-Performing Assets, Urban Co-operative Bank, Assets, Provisions
\end{abstract}

\section{INTRODUCTION}

Co-operation is a special method of doing work jointly and suits the poor more than the rich. The rich, however, are not precluded from coming with its fold. All those who want to co-operate must, as a condition precedent, have a common need and to fulfill it, should agree to work selflessly (Bedi). The origin of Indian Co-operative Credit Movement can be traced as far back as to 1844 as per the Report of Woodhead Famine Commission of Bengal Province. The said commission recommended that credit should be given at low rate of interest to the needy people. The Maclagan
Committee's recommendations (1914) have much to contribute in evolving the urban cooperative credit movement and such banks have started developing in all the states of the nation (IIBF). Banking is a service industry. The main objective of the banking is to provide the financial support to its customers / members in co-operatives. The Urban Co-operative Banks (UCBs) occupy a significant place in the urban credit movement. The urban co-operative credit movement started in India with the chief object of catering to the banking and credit requirements of the urban middle class. The need for organization of UCBs was felt to provide helping hand to weaker section of urban community viz., small traders, artisans, salaried people, professionals and other people of small means. These banks were expected to spread banking habits among people in the cities, towns and semi-urban areas (Abdul Kuddus and Zakir Hussian).

\section{REVIEW OF LITERATURE}

Bhavani Prasad G V and Veena D (2011) in their study on 'NPAs in Indian Banking Sector - Trends and Issues', had evaluated the operational performance of the SCBs in India since 2000, NPAs Trends and issues. This Study concluded that PSBs, which currently account for more than 78 percent of total banking industry assets are saddled with NPAs, falling revenues from traditional sources, lack of modern technology and a massive workforce while the new private sector banks are forging ahead and rewriting the traditional banking business model by way of their sheer innovation and service and adoption of modern technology. Gurumurthy (2008) in his study based article observed that, the letters 'NPA' strike terror in banking and business circles today. The first issue is when the Indian economy is not performing, can non-performing accounts in banks be avoided? Another point, many western scholars are coming round to the view that the infamous Washington Consensus, which is the mother of the idea of globalised NPA norms, is a failure. They now say that domestic finance should be based on counter cyclical approach, that is, if the economy is under-performing there should be liberal financing to lift the economy. Today's NPA policy is precisely the other way round. Universalised NPA rule is a western strategy to keep global banking and finances under its thumb. It is tailor made to suit equity-driven economies, that is, the Western ones. 
Siraj K K and Sudarsanan Pillai P (2012) in their Study on the 'Performance of Non-Performing Assets (NPAs) of Indian Banking during Post Millennium Period'. Had observed that NPA is a virus affecting banking sector. It affects liquidity and profitability, in addition posing threat on quality of asset and survival of banks. This study explored movement of various NPA indicators; Gross NPA, Net NPA, Additions to NPA, Reductions to NPA and Provisions towards NPA and compares it with Total Advances and Total Deposits of banks. Amit Basak (2009) in his study on 'Performance of Bantra Urban Cooperative Bank in West Bengal: An Appraisal', identified that the operational efficiency was unsatisfactory and characterized by low profitability, ever growing non-performing assets (NPA) and relatively low capital base.

Sugate Marjit and Indrajit Mallick (2004) in their study stated that in recent years there has been increasing concern over the financial health of banks in different economics. The non-performing assets problem has secured an important place not only in the limited sphere of regulatory policy discussion in banking but also in general public discussion on the safety and soundness of financial institutions. This study attempted to understand an aspect of this important problem and to contribute to a better understanding of potential regulatory policy, which can mitigate this problem.

\section{CONCEPT AND AIM OF THE STUDY}

The definition of Non-Performing assets (NPAs), drawing on the norms of Income Recognition, Assets Classification and the Provisioning (IRAC) requirements in India Banking System, has been developed during the post-reforms era as a follow up of the recommendation of the Narasimham Committee on Economic Reforms. This concept into effect for implementation from April 1992 when RBI introduced the Prudential Accounting Standards for banks which essentially among other things, paved the way for banking sector reforms that followed. The Prudential Norms of Income recognition, assets classification, provisioning and capital adequacy which were applicable to commercial banks since 1992 under the financial sector reforms were also made applicable to Co-operative Banks from 1996-97. The co-operative banks have since then been recognizing their non-performing assets both in absolute and relative terms and making provisions thereof (RBI).Hence, the expanding NPAs in banking Industry is a major concern for banking industry. NPAs affect the performance of banks and growth in NPA which bring down the entire profitability of the sector. In backlash of this situation, the core objectives of this empirical study to bring the real status and conditions of Non-Preforming Assets in Urban Co-operative Banks in Coimbatore District of Tamil Nadu. Further, the study can explore the factual outlook and effects of the same on different heads such as assets classifications (Standard asset, sub-standard, Doubtful Assets 1(D1),D2 and D3 Assets, Loss Assets, Sector-wise analysis, Gross and Net NPAs etc., all about, the findings of this empirical study can give a better understanding about the sector to the people who are associated with academic, research scholars, banking professionals, policy makers and consultant are in particular and allied groups are in general.

\section{METHODOLOGY}

This study is an Empirical Research and Survey Method in nature. Secondary data were gathered. The secondary data were collected through constructive questionnaire from the records, registers, and financial statements, official websites of the Sample Banks, etc., apart from that, similar other studies / published articles were also considered to this study. Coimbatore is one of the biggest audit zone which covers Urban Co-operative Banks in five districts; Coimbatore, the Nilgiris, Erode, Namakkal and Krishnagiri. Moreover Coimbatore district is the second largest district in the state of Tamil Nadu and had higher banking transactions more urban coverage and early origin. Hence Coimbatore District was purposively selected for the study. This District was bifurcated into Coimbatore and Tiruppur District in 2008. But this study is confined to the earlier Coimbatore District covering Tiruppur District also.

At time of study, there are $130 \mathrm{UCBs}$ in 32 districts of Tamilnadu state. The urban cooperative banks under study were Coimbatore UCB (CUCB), Mettupalayam UCB (MUCB), Pollachi UCB (PUCB), Umumalpet UCB (UUCB), Tiruppur UCB (TUCB) and Valparai UCB (VUCB). Coimbatore is the third largest city in Tamilnadu, according to the 2011 census population of the Coimbatore district is 3458045 . With more than 30,000 small, medium and large industries, the city's primary industries are engineering and textiles. The district also houses the country's largest amount of hosiery and poultry industries. Mettupalaym is a taluk headquarters of Coimbatore district. It is located in the foot hills of Nilgiri hills. Pollachi is a leading commercial center and is situated $40 \mathrm{~km}$ south of Coimbatore. Next to Coimbatore it is the leading town of the district. Udumalpet is municipal town and also an industrial town, since a number of textile, paper and variety of industries has been established here and in the agricultural field too. Tiruppur is the Seventh largest city in Tamil Nadu. It is an obscure town in Coimbatore district has been placed in the knitwear map of global apart from catering to the whole India. Valparai is a hill area with tea and coffee plantations on the Anamalai mountain range. Five of the six selected banks CUCB, PUCB, MUCB, UUCB and TUCB had earlier emergence that is prior to 1930. Whereas the Valparai Urban Cooperative Bank (VUCB) was organized only on 1949. All the 6 Urban Cooperative Banks in Coimbatore District were selected for the study. The study had covered a decadal period i.e., from 2000-01 to 2010-11 for taking into gather data and analysis.

\section{ANALYSIS AND RESULTS: CORE FINDINGS OF THE STUDY}

\section{A. Gross NPA (GNPA)}

Gross NPAs are the sum total of all loan assets of which interest and or principle of installments has remained due as 
on Balance Sheet date. Gross NPA reflects the quality of the loans made by banks. It consists of all the non-standard assets viz., sub-standard, doubtful and loss assets. The GNPA of the banks under study are presented below. The gross NPA of the selected banks had decreased by about 16 percent during the study period. The amount stood at Rs.2014 lakhs during 2010-11 which was more than the District average Rs.17.26 at National level. The Gross NPA with regard to individual banks highly fluctuated. The performance of MUCB and TUCB in this regard is good as their GNPA had reduced by 43 percent and 33 percent respectively during the study period. On the contrary, the Valparai UCB's GNPA had increased by 126 percent over the study periods. The overall picture shows that the GNPA of CUCB had higher GNPA than other banks. However higher GNPA is due higher loan outstanding. A decreasing trend is witnessed with regard to the Gross NPA of each of the selected banks except Valparai and Udumalpet UCBs. However the variation in the trend of Valparai UCB is very high when compared with UUCB. The total Gross NPAs of the banks which stand at Rs.2014 lakhs may increase to Rs.2914 lakhs after 10 years i.e. 2020-21. A comparison of actual GNAPs with trend values reveal unmatching figures for different banks which evidences considerable fluctuations in actual figures.

\section{B. Net NPA (NNPA)}

Net NPA is denoted as GNPA (-) Provision for NPA made. Net NPA shows the actual burden of banks. The provisions against the NPAs are to be made as per RBI guidelines.

1. NNPA Magnitude and Trends: The yearly Net NPA of the selected banks had much variation during the study period. It stood at Rs.1654 in the year 2000-01 and increased considerably in 2001-02 and was declining thereafter. However the net NPA of UUCB had increased by 46 percent and that of Valparai UCB increased by 2.4 percent over the 11 years period. The decadal average net NPA of the banks put together was Rs.2426 lakhs which is lower than the state average of 2040 at National level. Since the net NPA figures fluctuate considerably, the linear trend value does not match with actual figures. However the trend was a decreasing one and evidences increased provisions for NPAs. Based on the trend values, it is projected that the net NPA will be in the order of Rs.6086 lakhs during 2020-21.

\section{Classification of Assets of NPAs in UCBs of Selected Region}

The foregoing finding explores the results of the various classifications of assets on NPAs in selected region.

1. Standard Assets: Higher the standard assets, higher will be the financial strength of the banks. The standard assets of the banks had increased from Rs.16333 lakhs in 2001-01 to Rs.18803 lakhs in 2010-11 (i.e. an increase by 15 percent). The decadal average amount of standard assets of all the banks put together was Rs.14860 lakhs with a standard deviation of 1840 . On an average 81.4 percent of the loans outstanding of the banks were standard assets. This proportion is on increasing trend with CUCB, MUCB and TUCB and was decreasing in other banks. The proportion of a standard asset to loans outstanding was comparatively low with VUCB.

2. Sub-standard Assets: Sub-standard assets of the bank have decreased over the study period. However wider fluctuations were noted in almost all banks. On an average 10.2 percent of the loans outstanding were of sub-standard assets. Substandard assets were very low with the Tiruppur UCB (7.2\% of loan outstanding) and high with Udumalpet UCB (12.2\% of outstanding loans). It is evident from the analysis that the sub-standard assets had come down considerably in recent years.

3. Doubtful Assets-I: The amount of doubtful assets was Rs.274 lakhs in 2000-01 which had decreased to Rs.115 lakhs in 2010-11. The proportion of these assets to total loan outstanding varied between 0.55 and 5.23 percent with an average of 2.62 percent. The amount of doubtful I assets were at high end during the first half of the study period and started declining considerably. Doubtful assets were comparatively high in the Valparai UCB and low in Udumalpet UCB.

4. Doubtful Assets-II: The average amount of doubtful II assets was Rs.458.90 lakhs in the banks. The standard deviation is 264.7 which evidence high variations in the figures. Though the amount of doubtful debts were increasing upto the year 2004-05, it moved downward from the year 2005-06. It is concluded that the amount of doubtful II assets were meager (i.e only $2.6 \%$ of total loans outstanding).

5. Doubtful Assets-III: Doubtful assets III of the banks had constituted only 1.77 percent of the total loans outstanding of the banks. The average amount of these assets was Rs.316.45 lakhs with a standard deviation of 180 . The doubtful III assets were more with the Valparai UCB and accounted for about 31 percent of its loan outstanding in 2010-11. It is interesting to note that the UUCB did not have doubtful III assets during the initial years of the study and even after that its proportion to loan outstanding was in fractions.

6. Loss Assets: The decadal average loss assets of the banks were Rs.217.36 lakhs and constituted only 1.22 percent of the loans outstanding. Mettupalayam UCB did not have any loss assets and it was very low with Coimbatore UCB and Pollachi UCB. The amount started shooting up in Valparai $\mathrm{UCB}$ in recent years and accounted for 11.21 percent of loans outstanding in 2010-11.

\section{Bank-wise NPAs in the selected region}

To have a clear understanding about each of the selected banks in relation to various assets under NPA. The 
following findings as results will provide the position of various assets under NPA bank-wise.

1. NPA in CUCB: In the Coimbatore UCB, 82.34 percent of the loans outstanding were of standard assets and only 16.40 percent were NPA. The decadal average NPA of the bank was Rs.1313.7 lakhs of which 70.45 percent were substandard assets which have less risk in recovery. Loss assets accounted for only 1.06 percent of the NPAs

2. NPA in MUCB: Eighty Two percent of the assets of the Mettupalayam UCB were of standard assets. The average per year NPA of the bank was Rs.437.27 lakhs of which, a majority (i.e. 44 percent were sub-standard Assets). The Bank did not have any loss Assets throughout the study period. Doubtful assets constituted about 55 percent of the total NPA.

3. NPA in PUCB: In the Pollachi UCB, 78 percent of the loan Assets were standard assets and 22 percent were NPA. The higher NPAs during the initial years of the study started decreasing after the year 2003-04 which is a good sign of its development. On an average, 51 percent and 2 percent of the NPA were doubtful and loss assets respectively.

4. NPA in UUCB: The standard asset of Udumalpet UCB was 83 percent of the total loan assets and 18 percent were NPA. Of the NPA more than 75 percent were substandard assets. Compared to other banks the doubtful and loss assets were low in this bank and constituted only 24 percent of the NPA. The proportion of various assets under NPA varied significantly during different years of the study.

5. NPA in TUCB: In the Tirupur Urban Cooperative Bank, about 84 percent of the loan assets were of standard assets. Of the NPA ( $16 \%$ of the loan outstanding) major portion i.e. 46.05 percent were substandard assets followed by doubtful assets (27 percent). As high as 27 percent of loans outstanding were noted to be loss assets. It is clear that the amount of Non-performing assets of various types were declining from the year 2003-04.

6. NPA in VUCB: Valparai Urban Cooperative Bank's standard assets were only 49 percent of the loans outstanding and ranks last among the banks under study. The situation was very worst during the year 2005-08 and started improving after 2008-09. In the same way, it has very high doubtful and loss assets i.e. 67 percent and 15.64 percent respectively. Hence it is concluded that the performance of the VUCB with respect to NPA is comparatively very poor.

\section{E. Sector-wise NPAs in the study region.}

A major portion of the NPA of the Coimbatore CUCB was house loans followed by non-farm sector loans. Jewel loan NPA was the minimum. NPA in weaker section loans was about 13 percent of the total NPA. It is concluded that more than 75 percent of the NPA of Coimbatore UCB were with house mortgage loans and non-farm sector loans.
1. Sector-wise NPA in MCUCB: The UCBs lend for various purpose/sectors and these sectors include Jewel Loan (JL), Housing Loan (HML), Non-Farm Sector Loan (NFS), Weaker Section Loan (WSL) and the others which include educational loan, Tamilnadu Minority Corporation (TAMCO) loan, Tamilnadu Backward Class Development Corporation (TABCEDCO) loan, handicapped loan, maternity loan, surety loan, etc., Of the total NPA of Mettupalayam UCB, $52.5 \%$ and 22.07 percent were with House mortgage loan and non-form sector loan respectively. Lesser percentage of weaker section loan NPAs were due to lesser such loan issues and outstanding. NPAs in all sectors had decreased considerably over the study period.

2. Sector-wise NPA in PUCB: NPA in all the five sectors individually had been decreasing from 2002-03. On an average 55.87 percent and 22.49 percent of the NPAs of the Pollachi UCB were with house mortgage loan and non-farm sector loans respectively.

3. Sector-wise NPA in UUCB: Sector wise NPA of the Udumalpet UCB shows a fluctuating trend. On an average 3.88 percent, 52.09 percent, 22.95 percent, 13.26 percent and 7.82 percent of the total NPA of the bank were Jewel Loans, HML, NFS, WSL and others respectively.

4. Sector-wise NPA in TUCB: A declining trend is noticed in the sector wise NPA of the Tiruppur UCB. A major portion of the total NPA of the bank with house mortgage loans. The NFS and weaker section loan NPAs constituted almost an equal proportion i.e., 13 percent. A considerable proportion of the NPA was with Jewel loans (11.26 percent).

5. Sector-wise NPA in VUCB : More than 53 percent of the total NPA of the Valparai UCB was with House mortgage loan followed by non-farm sector loans. Year-wise analysis shows that the NPA in each of the sectors, though fluctuating, had increased over the 10 years period.

6. Sector-wise NPA of All Banks: The overall picture shows that of the total NPAs of the UCBs in Coimbatore district, a major portion was with house mortgage loans i.e., 53.34 followed by non-farm sector loans. NPA with WSL and JL constitute 13.43 percent and 5.32 percent of the total NPAs of the bank respectively.

\section{F. NPA in Secured and Unsecured Loan}

A decreasing trend is noticed in secured loan. The amount of total secured loans stood at Rs.2235 lakhs in 2000-01 which had increased to Rs.42384 lakhs in 2002-03 and after that it had declined to Rs.1864 lakhs in 2010-11. The amount of unsecured loans had also decreased in except in MUCB and VUCB. The average of unsecured loans was 20.50 percent. NPA in secured and unsecured loans in relation to their respective loans outstanding shows that NPA in unsecured loans are more than that in the secured loans. 


\section{G. NPA Provisions in UCBs of the selected region}

1. NPA Provisions in CUCB: The total provision excluding the provision for standard assets form the NPA provisions. The amount of NPA provisions stood at Rs.129.1 lakhs in 2000-01 which had increased to Rs.303.1 lakhs in 2004-05. Thereafter the amount had been decreasing.

2. NPA Provisions in MUCB: The total NPA provision of the Mettupalayam UCB was Rs.62.6 lakhs which had increased to Rs.74 lakhs in 2010-11. Yearly variation are not so significant. Absence of loss assets provision is a good feature. However the provision for doubtful assets in the total NPA provision was 81 percent and among this D3 alone constituted a major portion. The average yearly provision for substandard assets was only 19 percent (SD 10.96) of the total provisions.

3. NPA Provisions in PUCB: The total NPA provisions of the Pollachi UCB had been increasing upto the year 200405 and steadily declining considerably. Yearly average. Of NPA provision was Rs.131.18 lakhs. The provision for D3 assets was notably high followed by for D2. Provision for loss assets was also considerable i.e. about 9 percent of total.

4. NPA Provisions in UUCB: Provision for substandard assets and loss assets were at high end. Low provisions for doubtful debts is a good sign but this shadowed by increased provisions for loss assets. The total provisions for NPA however were low and yearly average stands at Rs.36.7 lakhs with a S.D. of 16.

5. NPA Provisions in TUCB: The total NPA provision was Rs.144.2 lakhs in 2000-01 which had increased to Rs.643.3 lakhs in 2004-05 and thereafter steadily decreased of the total NPA provisions, the loss assets provisioning constitute a major part i.e. 70 percent. The provision for doubtful assets formed only 19 percent. The provision for substandard assets showed a declining trend over the years.

6. NPA Provisions in VUCB: The total NPA provision of the Valparai UCB had been increasing over years; it had increased enormously from Rs.18.1 lakhs to Rs.41.60 lakhs during the study period. Provisions for sub-standard assets during the initial four years were high compared to other risk assets. It is very clear from the study that the provision for D3 and Loss assets of the bank in recent years were very high which as not a desirable feature.

7. NPA Provisions- All Banks: The total provision of the banks increased from Rs.412.86 lakhs in 2000-01 to Rs.1395.5 lakhs in 2004-05. Thereafter the amount started declining. No doubt the provision matches with the total
NPAs. Of the total provision made by the banks under study, 23.35 percent were for Sub-standard Assets and 27.31 percent were for Loss Assets. Out of the provision for Doubtful Assets, 23.90 percent, 35.47 percent and 40.61 percent were for D1, D2 and D3 assets which lead to the conclusion that provision for D1 were more than the other two doubtful assets, D2 and D3. Standard Deviation of the provision for various assets denotes high fluctuations in the yearly provisions. It is clear that out of the total provisions only 0.46 percent were for standard assets.

\section{CONCLUSION}

The burgeoning NPAs in banking Industry are a matter of deep concern. It is just not a problem for banks but also proves fatal to the economic growth of the country. NPAs reduce the profitability of banks, weaken its financial health and erode its solvency. In this chapter, an attempt has been made to give A Conceptual Framework on Non-Performing Assets (NPAs) with Special reference to Urban Cooperatives banks in India. In this situation, the mounting and level of NPAs in Urban Co-operative Banks in Coimbatore District are in higher nature and same trend must be monitored and reduced tremendously for the wellbeing of the banking operations. The future drive and trust earnest on urban co-operative banks are to be determined based on their efforts/ practices on reducing their level of NPAs. It's a high time and alarming situation to all UCBs in southern region of Tamil Nadu must be awakened to formulate new strategies/ methods or work force for reduce their mounting level of NPAs towards banking sustainability.

\section{REFERENCES}

[1] Bedi, R.D. (1983). Co-operation in Theory, History and Practice of Co-operation. Loyal Book Depot, India, $12^{\text {th }}$ ed, 16-19.

[2] Abdul Kuddus, K.A. \& Zakir Hussian, A.K. (2011). Cooperative Credit and Banking, $2^{\text {nd }}$ ed., Limbra Publications, India. 289-295

[3] Indian Institute of Banking \& Finance (2011). Co-operative Banking, $1^{\text {st }}$ ed., Macmillan Publishers India, INDIA. 13-20.

[4] Bhavani Prasad, G.V., \& Veena, D., (2011). NPAs in Indian Banking Sector- Trends and Issues. Journal on Banking Financial Services \& Insurance Research (JBFSIR), 1(9), 67-84.

[5] Siraj, K.K., \& Sudarsanan Pillai, P. (2012). A Study on the Performance of Non-Performing Assets (NPAs) of Indian Banking During Post Millennium Period. International Journal of Business and Management Tomorrow (IJBMT), 2 (3), 1-7.

[6] Amit Basak (2009). Performance of an Urban Cooperative Bank in West Bengal: An Appraisal. Indian Cooperative Review, 47(1).1-10.

[7] Sugate Marjit \& Indrajit Mallick (2004). Collateral Mentoring and Banking Regulation. Economic and Political weekly, 1259-1262.

[8] RBI, (2015). Financial Markets - An Assessment of Reforms. Retrieved from, https://www.rbi.org.in/scripts/PublicationsView.aspx?id=10874

[9] Gurumurthy, S. (2008). The NPA Rule that Kills Banks, the Economy Itself. Retrieved from http://www.deepalichandra.blogspot.com. 